\title{
Parents Perception of Cultural Tourism in Umuahia North and South Local Government Areas of Abia State
}

\author{
Enemuo, Ogechi Blessing (Mrs) \\ Department Of Home Economic/ Hotel Mgt.\& Tourism College Of Applied Food Sciences And Tourism \\ Parents Perceptions Of Cultural Tourism In Umuahia North And South Lgas Of Abia State Nigeria
}

\begin{abstract}
The understanding of the importance and the role art and culture play in the development of cultural tourism lies fully on the hands of the local community that has the art and cultural materials. This study investigated the perception of literate and illiterate parents, male and female on cultural tourism in Umuahia North and South Local Government Areas of Abia State. Data were collected from 188 randomly (94 from each of the local government areas) selected respondents. Questionnaire was used for data collection. T-test was used to analyse the data obtained at $0.05 \%$ level of confidence. The results showed that (1) There is no significant difference between the mean opinions of literate and illiterate parents on their perception of cultural tourism (2) There is no significant difference between the mean opinions of male and female points on their perception of cultural tourism. From the results obtained, conclusions were drawn and recommendations made.
\end{abstract}

\section{Introduction}

The increased interest on global forces and flow has pushed notions to the local more than ever to the forefront of scholarly analysis (Salazar, 2005). Local and local heritage have found consumer market in global cultural flow and transnational movement of tourists with popular local culture commodities such as the cultural festivals and the wander in Umuahia north and south Local Government Areas positioned to meet tourist expectations. These in turn perceived as having particular implication for both the indigenous heritage as well as people being consumed. Cultural tourism is the movement of persons to cultural attractions away from their normal place of residence with the intention to gather new information and experience to satisfy their cultural needs (Richards, 1996).Cultural tourism refers to a segment of tourism that places special emphasis on cultural attractions. These attractions are varied and include performances, museums, displays, art museums, traditional religious practices, handcrafts and cultural practices (WTO, 1997) Culture and materials produced through cultural belief which can be in form of art, festivals, architectural structure (monument), artifacts are the bed rock of cultural tourism development. This simply means that art and cultural materials are motivators of cultural tourist. Holden (2008) noted that tourism is a highly complicated amalgam of different parts; these include the environment of where people come from and where they go to. This implies that cultural tourism is also motivated by man's quest to understand the ancient culture, the authentic meaning of the cultural materials used by the past society to solve their cultural, psychological and physical problems and how the ancient knowledge has help the contemporary society in handling their cultural, social and psychological problems.

Given the fact that tourism can flourish in an area only with the support of the area's residents, it is felt that attitudes and perception of residents towards tourism development and impact servers as crucially important input in identifying the strategic and managerial priorities of tourism ( Ekrem, Fuat, Huseyin \& Sedat 2002). How people understand culture and materials produced by it, affects the ways cultural materials are managed or used. This means that proper understanding of the importance of culture and its products will aid in its proper preservation which will lead to suitable cultural tourism environment. Environment in this context, cultural environment is the key component of tourism. Evidently tourism would not exist without us having favourable perception of the cultural attraction that exists in destination environment. As Urry (1995) observed, a person's wish to visit a particular environment is something that is socially constructed as depends upon developing a 'cultural desire' for a particular landscape. Critically man's understanding of culture plays a vital role for his desire for a particular cultural destination and his attitude towards the preservation and conservation of cultural materials.

Cultural tourism involves marketing of culture. Peoples' understanding of their culture and the importance of their cultural heritage plays an important role on how they can be packaged for tourism. When there is a proper perception of the impact the cultural material in cultural tourism development, there will be a great chance of sustainable cultural tourism development but where there is poor perception of the importance of culture and cultural materials by the local community chances of cultural tourism development in such area will be very minimal. 
According to WTO (1997) culture and tourism interact in various ways. Firstly, the impact of tourism on the host culture and society. The ways tourism activities interact with the cultural of host community is an important relationship between culture and tourism. According to Fox (1997) in Geoffrey and Alister (2006) the cultural impact of tourism are the ways in which tourism is contributing to changes in value systems, individual behavour, family structure, moral conduct, creative expression, traditional ceremonies and community organization. Secondly cultural patterns of a society influence its citizens and their ability and desire to travel. Such influence may be described as culture shaping inbound travel motivation (WTO, 1997). Culture material and arts are the pulling forces that motivate a tourist to visit a cultural tourism destination or a local community that has unique and authentic cultural materials.

WTO (1997) further explained that three variants of culture useful in assessing the three levels of the tourism-culture relationship are;

i. Culture as a value system relating to intellectual, spiritual and aesthetic development.

ii. Culture as summarizing the whole "way of life" of a people.

iii. Culture as the work or products of intellectual and artistic endeavours. When culture as an influence on outbound tourist motivation or the impacts of tourism is considered, the first theme value system of the term is most useful. On the other hand, when tourism as an influence on inbound tourism is at issue, the second and third themes (way of life and cultural products are most relevant (WTO, 1997). People from various cultural groups portray different behavior toward outbound tourism. Some culture will allow for socialization and experimentation of visited culture while other will strongly prefer their own culture. This means the cultural trait of an individual play a vital role on his behavior on a visit to other culture.

Authenticity of art and cultural materials are the main motivators for cultural tourist, the knowledge of the owners of art and cultural materials and the importance of such materials will determine how the material will be preserved. Lack of knowledge and understanding of the importance of art and cultural materials will have negative effect on how the cultural material will be presented by the local communities that own them.

Tampering with the art and cultural material which portray the culture of a given society affects the authenticity of the history, ancient civilization and cultural life of the past society that produced them, this also has negative effect on the contemporary society. Urry (1990) noted that, authenticity as a concept has relevance in cultural tourism, on the one hand tourism promotes authentic experience and on the other hand needs to commodify cultural assets to market them as consumable product. Local cultures visible through costumes, rituals, flok and ethnic arts are the environment for cultural tourism development. The understanding of their importance by the local communities where they are located plays a vital role for sustainable cultural tourism development.

The perception of local community on the importance of art and cultural materials also determine the standard of cultural forms for tourist consumption via package and marketing (Swain, 1993) where there is misunderstanding or gap between the local community and art and cultural material in their environment, it will be difficult for sustainable cultural tourism development to exist in such community. When there is a proper understanding of the importance of arts and cultural materials by the locals it will difficult for them to loss of meaning of cultural materials as a result of influx of tourists to exist in such community

\section{Objectives Of The Study}

This study was designed to determine the perception of parents in Umuahia North and South Local Government Areas. Specifically, the study seeks to

1. Identify how literate and illiterate parents in Umuahia North and South LGAs understand cultural tourism

2. Determine the understanding of cultural tourism by male and female in Umuahia North and South LGAs

\section{Hypothesis}

The following hypothesis guided the study at 0.5 level

1. There is no significant difference between the mean opinions of literate and illiterate parents on their perception of cultural tourism.

2. There is no significant difference between the mean opinions of male and female on their perception of cultural tourism.

\section{Design And Areas Of The Study}

It was a survey. The area of the study was Umuahia North and South Local Government Areas of Abia 


\section{Population For The Study}

The study population comprised of 48 (literates) 48 (illiterates) 46 (male) and 46 (female) drawn from Umuahia South Local Government Area of Abia State.

Sample

Random sampling technique was used to obtain a representative sample of 120 respondents.

\section{The Instrument}

The instrument for data collection was questionnaire. It was developed based on extensive literature review, guided by the research objectives.

\section{Data Collection}

A total of 188 copies of the questionnaire were distributed by us. All the copies were retrieved and analyzed, using T-test at 0.05 level of confidence.

\section{Presentation Of Results}

$\mathrm{HO}_{\mathrm{I}} \mathrm{T}$-test comparison of literate and illiterate on their perceptions of cultural tourism

\begin{tabular}{llllllll}
\hline Subject: & $\mathrm{N}$ & Mean & $\mathrm{SD}$ & $\mathrm{SE}^{+}$ & $\mathrm{df}$ & $\mathrm{t}^{1}$ & 0.05 \\
\hline Literate & 48 & 2.56 & 0.61 & 0.05 & 94 & 0.72 & $\mathrm{NS}$ \\
\hline Illiterate & 48 & 2.44 & 0.55 & & & \\
\hline
\end{tabular}

$\mathrm{SE}^{+}=$Pooled Standard Error for the two groups. The results above showed that calculated t'test (0.72) is less than t-critical (1.96). $\mathrm{HO}_{1}$ above is therefore accepted. Therefore there is no significant difference between the mean opinions of literate and illiterate parents on their perception of cultural tourism.

$\mathrm{HO}_{2}$ T-test comparison of male and female parents on their perceptions of cultural tourism

\begin{tabular}{llllllll}
\hline Subject: & $\mathrm{N}$ & Mean & $\mathrm{SD}$ & $\mathrm{SE}^{+}$ & $\mathrm{df}$ & $\mathrm{t}^{\mathrm{t}}$ & T critical \\
\hline Male & 46 & 2.52 & 0.91 & 0.05 & 90 & 0.3 & NS \\
\hline Female & 46 & 2.50 & 0.26 & & & & \\
\hline
\end{tabular}

$\mathrm{SE}^{+}=$Pooled Standard Error for the to groups

The results above sowed that the calculated t-test $(0.30)$ is less than the table t-value of (1.96) Therefore, $\mathrm{HO}_{2}$ is accepted. There is no significant difference between the mean opinion of male and female on their perception of cultural tourism.

\section{Discussion}

Finding from table (1) shows that there is no significant difference on the perception of literate and illiterate parents on cultural tourism in Umuahia North and South Local Government Areas. This is consistent with the view of Holloway (2006) that state that tourism creates opportunity for a citizen to understand his national identity and a full sense of belonging to a culture. The understanding of cultural tourism plays a vital role in the preservation and conservation of material culture which are the hallmark for the development of cultural tourism. The literate and illiterate parents in Umuahia have the knowledge that of the importance of cultural tourism.

Table (2) also revealed that there is no significant difference in the perception of cultural tourism among male and female in the Umuahia North and South local government areas. The understanding of the importance of cultural tourism by the people of Umuahia North South showed itself on their participation in the UgwuAbia Cultural Festivals from 1996-2008. It is also manifested on how some of the local cultural festivals that portray the culture of the areas like Ekpe festival, New Yam Festival and other cultural sites and activities that portray the culture of the area are conducted. As WTO (1997) rightly pointed out that culture and tourism interact in various ways, the understanding of cultural tourism has helped in the showcasing of the culture of the people of Umuahia South and north Local Government Areas.

The study also agrees with Fox (1977) in Geoffery and Alister (2006) because cultural activities of the areas which are been admired by tourists has really led to economic development in the areas based on the fact the activities have made people to visit the areas when the cultural activities are been conducted.

\section{Conclusion/Recommendations}

1. Both literate and illiterate parents and knowledge in the area have very good understanding and knowledge of cultural tourism. For instance, during Ugwu-Abia cultural festivals, they showcase their cultural activities very well. This implies that the people of the areas of study need more encouragement from the government for effective preservation and conservation of their cultural materials which are the raw material for tourism development. 
2. Both male and female subjects have similar perception of cultural tourism in the area used for the study. The perceived cultural tourism as an important cultural activity that needed to be preseved for the future generation. This was seen in the different cultural activities based on gender. It s therefore essential that both government and non-government organization support cultural tourism in the Umuahia north and south Local Government Areas.

\section{References}

[1] Ekrem,T , Fuat, E, Huseyin, O .\& Sedat. A. (2002). Resident perception of the impact of tourism in a Turkish Resort Lown. Annals of Tourism Research, 12(4) 432-438

[2] Geoffery, W and Alister M (2006) Tourism: Change, Impacts and Opportunities England Pearson Education Limited. Edinburgh gate

[3] Holden, A (2008) Environment and Tourism Abingdon Routledge 2park square Milton park

[4] Richards, G (1996) Cultural Tourism in Europe UK Wallingford Oxon. CAB Internation.

[5] Swain, M.B (1993) Women producers of Ethnic Arts, Annals of tourism research.

[6] Urry, J (1990) The Tourist Gaze. London stage Publications

[7] Urry, J (1995) Consuming Places, London. Routledge

[8] WTO (1997) International Tourism: A Global Perspective. Madrid Spain pub: World Tourism organization. 